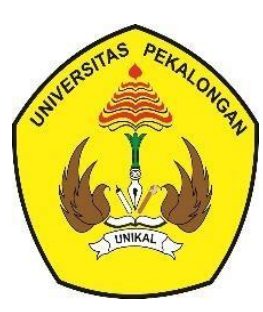

Pena Justisia: Media Komunikasi dan Kajian Hukum

Volume 18, No.2, 2019

Artikel Hasil Penelitian

\title{
STATUS HUKUM TANAH KERATON KASEPUHAN CIREBON SETELAH BERLAKUNYA UNDANG-UNDANG NOMOR 5 TAHUN 1960 TENTANG PERATURAN DASAR POKOK-POKOK AGRARIA
}

\begin{tabular}{|c|c|}
\hline \multicolumn{2}{|c|}{$\begin{array}{l}\text { Thanisa Dita Murbarani* } \\
\text { T* Fakultas Hukum Universitas Sebelas Maret Surakarta, Email: ditamurbarani@gmail.com }\end{array}$} \\
\hline Info Artikel & Abstract \\
\hline $\begin{array}{l}\text { Keywords: } \\
\text { Keraton; Land; Cirebon. }\end{array}$ & $\begin{array}{l}\text { This study aims to analyze and determine the legal status of the land of the Kasepuban } \\
\text { Palace in Cirebon after the enactment of Law Number } 5 \text { of } 1960 \text { concerning Basic } \\
\text { Agrarian Regulations. The results show that the legal status of the Kasepuban Sultanate } \\
\text { lands has been transferred to the state based on the Fourth Dictum letter A Law Number } \\
5 \text { of } 1960 \text { concerning Basic Agrarian Principles and the land is redistributed as the object } \\
\text { of the provisions regarding land reform on the legal basis of Article } 1 \text { Government } \\
\text { Regulation Number } 224 \text { of } 1961 \text {. It is very inversely proportional to assuming that the } \\
\text { Kasepuban Palace land is not and has never become self-government, then the legal status } \\
\text { of the Kasepuban Palace land is fully controlled as customary land / wewengkon land I } \\
\text { probibited forest belonging to the Kasepuban Palace Cirebon. The problem is, based on } \\
\text { authentic evidence, the Kasepuban Palace has never been self-governing, but the lands } \\
\text { controlled from generation to generation or the land of the Keraton Kasepuban Cirebon are } \\
\text { still redistributed by the government. So, the legal status of the Kasepuban Palace lands is } \\
\text { currently unclear. }\end{array}$ \\
\hline $\begin{array}{l}\text { Kata kunci: } \\
\text { Keraton; Tanah; Cirebon. }\end{array}$ & $\begin{array}{l}\text { Abstrak } \\
\text { Penelitian ini bertujuan untuk menganalisa dan mengetahui status hukum } \\
\text { tanah Keraton Kasepuhan Cirebon setelah berlakunya Undang-Undang } \\
\text { Nomor } 5 \text { Tahun } 1960 \text { tentang Peraturan Dasar Pokok-Pokok Agraria. Hasil } \\
\text { penelitian menunjukkan bahwa status hukum tanah-tanah Kasultanan } \\
\text { Kasepuhan telah beralih kepada negara berdasarkan Diktum Keempat hururf } \\
\text { A Undang-Undang Nomor } 5 \text { Tahun } 1960 \text { tentang Peraturan Dasar Pokok- } \\
\text { Pokok Agraria dan atas tanah tersebut diredistribusikan sebagai objek dari } \\
\text { ketentuan mengenai landreform dengan dasar hukum Pasal } 1 \text { Peraturan } \\
\text { Pemerintah Nomor } 224 \text { Tahun 1961. Sangat berbanding terbalik jika } \\
\text { diasumsikan bahwa tanah Keraton Kasepuhan tersebut adalah bukan dan } \\
\text { tidak pernah menjadi swapraja, maka status hukum tanah Keraton } \\
\text { Kasepuhan dikuasai sepenuhnya sebagai tanah adat/tanah } \\
\text { wewengkon/hutan larangan milik Keraton Kasepuhan Cirebon. } \\
\text { Permasalahannya, Keraton Kasepuhan berdasarkan bukti otentik tidak } \\
\text { pernah menjadi swapraja tetapi tanah-tanah yang dikuasai secara turun- } \\
\text { temurun atau tanah wewengkon Keraton Kasepuhan Cirebon tetap } \\
\text { diredistribusikan oleh pemerintah. Jadi, status hukum tanah- tanah Keraton } \\
\text { Kasepuhan saat ini tidak jelas status hukumnya. }\end{array}$ \\
\hline
\end{tabular}




\section{PENDAHULUAN}

Tanah merupakan sumber daya penting yang menyangkut kehidupan manusia yang sangat mendasar. Seperti yang diketahui bahwa tanah tidak dapat dipisahkan dari manusia karena tanah merupakan salah satu faktor penting dari kehidupan manusia. Dalam kegiatannya manusia banyak berhubungan dengan tanah. ${ }^{1}$ Hubungan tersebut antara lain bahwa tanah merupakan sumber mata pencaharian contohnya seperti bercocok tanam (pertanian) sehingga Indonesia dijuluki sebagai negara agraris karena banyak dijumpai tanah pertanian. Tanah juga merupakan tempat mendirikan bangunan untuk tempat tinggal dan untuk memakamkan orang yang meninggal dunia. Tanah harus dijaga, dimanfaatkan dan dilestarikan dengan benar dan sebaik-baiknya agar dapat mewujudkan kesejahteraan, perlindungan dan kepastian hukum bagi seluruh masyarakat. ${ }^{2}$

Namun karena kebutuhan manusia tidak selalu sama bahkan sering bertentangan, maka perlu adanya peraturan-peraturan, agar kebutuhan manusia dapat terpenuhi secara adil, karenea penerapan dan pelaksanaan keadilan dapat dilihat dari seluruh aspek sebagai pelaksanaan kehidupan. Sebagai konsekuensi logis dari negara kesatuan sesuai dengan UUD NRI 1945, bahwa di seluruh wilayah negara berlaku peraturan perundang-undangan yang sama. Untuk mewujudkan hal yang demikian, tentunya tidak mudah karena memerlukan proses konstitusional sebagaimana ditetapkan dalam UUD NRI 1945, terlebih apabila menyangkut kepentingan masyarakat luas khususnya dibidang pertanahan atau keagrariaan. Dalam bidang pertanahan karena belum bisa dibuat peraturan dengan segera setelah proklamasi kemerdekaan, maka sesuai dengan pasal II aturan peralihan UUD NRI 1945, digunakanlah ketentuan lama. Akibat ketentuan tersebut, di Indonesia terdapat dualisme hukum dalam bidang pertanahan, yaitu sistem hukum barat peninggalan jaman kolonial dan sistem hukum adat yang merupakan hukum asli bangsa Indonesia. ${ }^{3}$

Bangsa Indonesia sebagai bangsa yang merdeka berkeinginan untuk membentuk hukum tanah yang bersifat tunggal. Dengan telah diundangkannya Undang Undang Nomor 5 Tahun 1960 tentang Peraturan Dasar Pokok-pokok Agraria atau lebih dikenal dengan Undang Undang Pokok Agraria (UUPA) pada tanggal 24 September 1960, maka bangsa Indonesia telah memiliki hukum tanah Nasional yang berstruktur tunggal. Dengan mulai berlakunya Undang Undang Nomor 5 Tahun 1960 (UUPA) terjadi perubahan yang sangat fundamental pada Hukum Tanah di Indonesia. ${ }^{4}$ Perubahan itu bersifat mendasar/fundametal karena baik mengenai struktur perangkat hukumnya, mengenai konsepsi yang mendasarinya maupun isinya harus sesuai dengan kepentingan rakyat Indonesia serta memenuhi pula keperluannya menurut perubahan jaman. Sebelum berlakunya UUPA berlaku bersamaan berbagai perangkat hukum tanah di Indonesia. Ada yang bersumber pada hukum Adat yang berkonsepsi komunalistik religius, ada yang bersumber pada hukum Administrasi Belanda/Perdata Barat yang individual liberal dan ada pula yang berasal dari berbagai bekas Pemerintahan Swapraja yang umumnya berkonsepsi feudal. ${ }^{5}$

Dengan demikian UU No. 5 Tahun 1960 (UUPA) diberlakukan di seluruh wilayah Indonesia sebagai hukum tanah Nasional Indonesia. Demikian pula di daerah Swapraja di Kota Cirebon, Undang Undang tersebut berlaku pula terhadap tanah-tanah bekas Swapraja di Kota Cirebon.

\footnotetext{
${ }^{1}$ Septina Marryanti and Yudha Purbawa, 'Optimization of Factors That Affect The Success of Complete Systematic Land Registration’, BHUMI: Jurnal Agraria Dan Pertanahan, 4.2 (2018), 190-207.

2 Rahayu Subekti, Lego Karjoko, and Wida Astuti, 'Kebijakan Tata Ruang Di Kabupaten Kutai Kartanegara (Studi Valorisasi Ruang)', Yustisia Jurnal Hukum, 2.2 (2013) < https://doi.org/10.20961/yustisia.v2i2.10184>.

${ }^{3}$ Ahmad Nashih Luthfi, 'Reforma Kelembagaan Dalam Kebijakan Reforma Agraria Era Joko Widodo-Jusuf Kalla [Institutional Reform in the Joko Widodo-Jusuf Kalla Era of Agrarian Reform Policy]', Jurnal Bhumi, 4.2 (2018), 153 <https://doi.org/10.31292/jb.v4i2.276.g252>.

${ }^{4}$ Hardianto Djanggih ham Abbas, Marten Bunga, Salmawat, 'The Wife's Rights Over Mahar Sompa Of Traditional Marriage In Bugis Makassar (The Analysis of PA Decission Nomor 25/Pdt.P/2011/PABlk)', Kanun Jurnal Ilmu Hukum, 20.2 (2018), 203-18.

${ }^{5}$ Christina Sri Murni, 'Peralihan Hak Atas Tanah Tanpa Sertifikat', Lex Librum: Jurnal Ilmu Hukum, 4.2 (2018), 691 $<$ lexlibrum.id/index.php/lexlibrum/article/download/108/pdf >.
} 
Daerah Swapraja berati daerah yang memiliki Pemerintahan sendiri. Sebutan swapraja tidak terdapat di dalam Undang-Undang Dasar 1945, dalam penjelasan Pasal 18 disebut; Zelffesturende Landschappen. Baru di dalam Konstitusi Republik Indonesia Serikat dan Undang-Undang Dasar Sementara 1950 di jumpai sebutan swapraja, masing-masing dalam Bab II dan Bab IV. Di dalam II bagian III Konstitusi Republik Indonesia Serikat yang berjudul daerah Swapraja, dinyatakan dalam pasal 64 dan 65, bahwa; daerah-daerah Swapraja yang sudah ada, diakui. Mengatur kedudukan daerahdaerah swapraja masuk dalam tugas dan kekuasaan daerah-daerah bagian yang bersangkutan, dengan pengertian bahwa mengatur daerah itu dilakukan dengan kontrak, yang diadakan antara daerah-daerah bagian dengan daerah-daerah swapraja yang bersangkutan. ${ }^{6}$

Terhadap tanah-tanah bekas swapraja di Kota Cirebon tersebut berlaku ketentuan Diktum Keempat huruf A yang menyatakan bahwa tanah-tanah bekas Swapraja tersebut kembali kepada negara sebagai pengganti Swapraja. Dalam Bab IV Undang-Undang Dasar Sementara 1950 yang berjudul Pemerintah Daerah dan Pemerintah Swapraja, dinyatakan dalam pasal 32, bahwa kedudukan daerah-daerah swapraja diatur dengan Undang-Undang. UUPA dalam Diktum ke IV, masih menyebut adanya daerah swapraja dan bekas swapraja, namun demikian, hingga kini Peraturan Pemerintah yang secara khusus merupakan pelaksanaan dari Diktum ke IV UUPA huruf A tersebut, belum juga ada. Yang ada adalah Peraturan Pemerintah No. 224 tahun 1961 yang memuat ketentuan mengenai pembagian tanah swapraja dan bekas swapraja dalam rangka pelaksanaan Landreform. Peraturan Pemerintah Nomor 224 tahun 1961. Dengan diberlakukannya UUPA dapat dikatakan telah tercapai suatu kodifikasi dan unifikasi hukum agrarian di Indonesia. Akan tetapi, kenyataan menunjukkan masih terdapat kendala dalam melaksanakan ketentuanketentuan UUPA khususnya yang berkaitan dengan tanah-tanah swapraja atau bekas swapraja. Berbicara mengenai tanah swapraja atau bekas swapraja maka akan merujuk pada maslah tanah di wilayah Kerajaan atau Kasultanan. ${ }^{7}$

Dihubungkan dengan permasalahan yang ada tanah antara Pemerintah Kota Cirebon Provinsi Jawa Barat dengan pihak Keraton Kesepuhan Cirebon, pemerintah kota Ciebon beranggapan tanah tersebut masuk dalam tanah swapraja, sementara pihak keraton tanah eks keraton merupakan tanah turun temurun dari nenek moyang raja (tanah wewengkon). Pendistribusian tanah dilakukan melalui Panitia Landreform Kota Praja Cirebon. Dua anggapan yang berbeda dalam menginterprestasikan mengenai makna swapraja atau bekas swapraja,pihak Keraton Kesepuhan dan pihak pemerintah kota mempunyai argumen masing-masing mengenai pemaknaan swapraja atau bekas swapraja. Melihat pandangan yang berbeda, hendaknya pemerintah kota Cirebon dapat menetapkan terlebih apa indikator dari tanah swapraja tersebut. ${ }^{8}$

Penetapan indikator pemaknaan swapraja dengan bekas swapraja dalam kedudukan tanah Kesultanan Kesepuhan dengan melihat dari latar belakang historis, politis maupun yuridis keberadaan Kesultanan Kesepuhan Kota Cirebon. Dengan diterbitkannya surat Nomor 400-1581 tertanggal 24 Juni 2003 melalui Badan Pertanahan Nasional (BPN) yang ditujukan kepada Gubenur Provinsi Jawa Barat perihal Tanah Kesultanan Kasepuhan Cirebon yang berisikan bahwa tanah Kesultanan Kasepuhan Cirebon adalah tanah swapraja. Namun kenyataannya pihak Pemerintah belum bisa menjelaskan arti swapraja serta membuktikan mana saja yang termasuk kedalam tanah Swapraja atau bekas swapraja dan yang bukan tanah swapraja atau bekas swapraja. Kenyataanya kemudian, seluruhnya habis di-redistribusikan dan tidak ada sisa yang seharusnya dikembalikan

${ }^{6}$ L Kajoko, Zaidah Nur Rosidah, and I.G.A.K. Rachmi Handayani, 'Refleksi Paradigma Ilmu Pengetahuan Bagi Pembangunan Hukum Pengadaan Tanah', Bestuur, $7.1 \quad$ (2019), $1-14$ $<$ https://jurnal.uns.ac.id/bestuur/article/view/42694>.

${ }^{7}$ Dian Aries Mujiburohman, 'Potensi Permasalahan Pendaftaran Tanah Sistematik Lengkap (Ptsl)', BHUMI: Jurnal Agraria Dan Pertanahan, 4.1 (2018) <https://doi.org/10.31292/jb.v4i1.217>.

8 Ida Nurlinda, 'Perolehan Tanah Obyek Reforma Agraria (Tora) Yang Berasal Dari Kawasan Hutan: Permasalahan Dan Pengaturannya', Veritas et Justitia, 4.2 (2018), 252-73 < https://doi.org/10.25123/vej.2919>. 
kepada pihak eks Kesultanan Kasepuhan Cirebon. Hal inilah yang merupakan awal timbulnya "konflik pertanahan" di Kota Cirebon, yang terus berlanjut hingga saat ini."

\section{PEMBAHASAN}

\section{Pelaksansan Diktum ke IV huruf A UUPA di Wilayah Keraton Kasepuhan Cirebon}

Dilihat dari latar belakang sejarah, politis maupun yuridis, Kesultanan Cirebon tidak pernah menjadi daerah Swapraja, karena ia tidak pernah melakukan persetujuan politik apapun dengan Pemerintah Hindia Belanda, dan telah menyerahkan kekuasaan pemerintahannya sepenuhnya kepada Pemerintahan Inggris dibawah Gubernur Jenderal Raffles, dengan Akta perjanjian 20 Juli 1813. Sampai dengan saat diserahkannya seluruh kekuasaan pemerintahan oleh Kesultanan Cirebon kepada Inggris tersebut, Cirebon adalah suatu wilayah dengan pemerintahan yang benar-benar Merdeka, terlepas dari pengaruh dan kekuasaan pemerintahan Hindia Belanda. Dengan keadaan dan posisi tersebut, Cirebon tentu tidak dapat dikategorikan sebagai wilayah swapraja/bekas swapraja, sebab suatu wilayah swapraja/bekas swapraja harus tunduk kepada pihak yang memberikannya kekuasaan untuk memerintah, seperti halnya yang terjadi dengan daerah-daerah swapraja lain. Hal itu tidak berlaku untuk Kesultanan Cirebon. Setelah Pemerintah Inggris menyerahkan kembali penguasaan Hindia Belanda kepada Pemerintah Belanda, keadaan itu diteruskan oleh Pemerintah Belanda, dimana Cirebon dianggap sebagai daerah pemerintahan langsung dibawah Belanda. Cirebon sejak saat itu, adalah merupakan daerah kekuasaan langsung dan sepenuhnya dari pemerintahan Belanda. Oleh karena itu, Cirebon, tidak bisa dikategorikan sebagai daerah Swapraja/ bekas Swapraja. ${ }^{10}$

Pada sisi lain, pelaksanaan ketentuan Peraturan Pemerintah Nomor 224 tahun 1961 telah dilaksanakan tidak sesuai dengan ketentuan yang disyaratkan oleh ketentuan itu sendiri. Menurut Peraturan Pemerintah tersebut, terhadap tanah swapraja dan bekas swapraja yang beralih kepada negara, diberi peruntukan; sebagian untuk kepentingan Pemerintah, sebagian untuk kepentingan mereka yang langsung dirugikan karena dihapuskannya hak swapraja atas tanah itu dan sebagian untuk dibagikan kepada rakyat yang membutuhkan, menurut ketentuan-ketentuan dalam peraturan ini. Lebih lanjut ditentukan, bahwa; tanah yang diperuntukan bagi mereka yang langsung dirugikan, letak dan luasnya ditetapkan oleh Menteri Agraria, setelah mendengar Menteri Dalam Negeri dan Otonomi Daerah. Dengan latar belakang seperti itu, serta dengan mengacu kepada pendapat Prof. Boedi Harsono, SH, mengenai syarat suatu daerah untuk dapat disebut sebagai daerah swparaja/bekas swapraja, juga Peraturan Pemerintah Nomor 224 tahun 1961 dan kemudian membandingkannya dengan pelaksanaan re-distribusi terhadap tanah-tanah itu, adalah wajar bila terjadi penolakan keras oleh pihak eks. Kesultanan Kasepuhan Cirebon atas tindakan yang dilakukan Pemerintah Kota Cirebon terhadap tanahnya. ${ }^{11}$

Jadi pelaksanaan ketentuan Diktum ke IV huruf A UUPA dan Pasal 4 Peraturan Pemerintah Nomor 224 tahun 1961, mengenai tanah-tanah swapraja atau bekas swapraja di wilayah Eks Kesultanan Cirebon, khususnya terhadap tanah-tanah eks Kesultanan Kasepuhan Cirebon, telah menimbulkan "konflik pertanahan" yang berkepanjangan, kerena tidak adanya kejelasan mengenai status tanah tersebut. Hingga saat ini belum juga bisa diambil suatu kesimpulan yang tegas, apakah Cirebon merupakan daerah swapraja/bekas swapraja atau bukan. Secara historis, politis maupun yuridis, Cirebon bukan dan tidak pernah menjadi daerah Swapraja atau bekas Swapraja, karena

${ }^{9}$ Femi Earnestly, 'Analisis Kadar Klorida, Amoniak Di Sumber Air Tanah Universitas Muhammadiyah Sumbar Padang’, Jurnal Katalisator, 3.2 (2018), 89 < https://doi.org/10.22216/jk.v3i2.3392>.

10 Isdiyana Kusuma Ayu, 'Problematika Pelaksanaan Pendaftaran Tanah Melalui Pendaftaran Tanah Sistematis Lengkap Di Kota Batu’, Legality : Jurnal Ilmiah Hukum, 27.1 (2019), 27 <https://doi.org/10.22219/jihl.v27i1.8956>.

${ }^{11}$ Elfira Permatasari, Habib Adjie, and Hardianto Djanggih, 'Perlindungan Hukum Kepemilikan Tanah Absentee Yang Diperoleh Akibat Pewarisan', Varia Justicia, $14.1 \quad$ (2018), 1-9 $<$ https://doi.org/10.31603/variajusticia.v14i1.2052>. 
sepanjang sejarah berdirinya kekuasaan Kesultanan di Cirebon, Cirebon merupakan suatu daerah yang merdeka dalam arti yang sesungguhnya, karena tidak pernah disentuh oleh kekuasaan pemerintah Hindia Belanda. ${ }^{12}$

\section{Makna Keraton Kasepuhan Cirebon dan Status Hukum Tanahnya}

Kasultanan Kasepuhan tercatat dalam sejarah Indonesia sebagai Kerajaan Islam terbesar di Jawa bagian Barat yang berdiri pada abad ke XV, sekaligus menjadi salah satu pusat penyebaran Islam di Tanah Jawa. Namun, dibalik kebesaran sejarahnya itu, sampai saat ini masih tersisa masalah terkait hak-hak Kasultanan Kasepuhan atas asset yang berupa tanah wewengkon atau tanah hak turun temurun Kasultanan Kasepuhan. Dalam Hukum adat Jawa Barat dikenal dua macam hak milik, yaitu hak milik yang bebas dan hak milik yang terikat. Tanah hak milik yang terikat lazim juga disebut tanah milik komunal. Tanah milik komunal dapat dibedakan antara lain, sebagai berikut: ${ }^{13}$

a) Tanah norowito, gogolon, pekulen, playangan, kesikepan, dan sejenisnya yaitu tanah pertanian milik bersama dan para warga desa yang bersangkutan dapat memperoleh bagian untuk digarap baik secara bergilir maupun secara tetap dengan syarat-syarat tertentu;

b) Tanah titisara, bondo deso, kas desa yaitu tanah milik desa yang biasanya disewakan, disakapkan kepada warga yang hasilnya dipergunakan untuk biaya pemeliharaan desa seperti untuk memperbaiki jembatan, jalan, mesjid dan sebagainya;

c) Tanah bengkok, yaitu tanah milik desa yang diperuntukkan bagi pejabat desa yang hasilnya dianggap sebagai gaji selama mereka menduduki jabatan tersebut;

d) Tanah pusaka, yaitu tanah milik bersama suatu klan/suku yang para anggotanya hanya mempunyai hak menggarap.

Di samping itu dalam lingkungan hukum adat Jawa Barat juga dikenal tanah milik adat atas tanah partikelir yang dalam hukum tertulis hindia belanda disebut hak usaha yaitu wewenang untuk bertindak sebagai yang berhak sepenuhnya atas tanah dengan mengingat pembatasan-pembatasan dan kewajiban-kewajiban yang terikat pada hak itu sebagai mana ditentukan dalam S. 1912 No. 422 dan 613. Hak ini merupakan hak penduduk atas tanah partikelir, yang oleh van Volenhoven disebut bouw of bewerkingsrecht (hak usaha) dan berdasarkan S. 1912 N0. 422 dan 613 disebut erfpacht, tetapi tidak ada kaitannya dengan erfpacht yang tercantum dalam Burgerlijk Wetboek (BW). ${ }^{14}$ Sejak tahun 1960 masalah tanah atau agrarian di Negara Republik Indonesia mengalami perubahan yang sangat signifikan, yaitu dengan lahirnya Undang-undang Pokok Agraria Nomor 5. Dalam Undang-undnag ini menjelaskan bahwa ada 4 jenis tanah terkena landreform sehingga statusnya berubah menjadi milik negara, yaitu : ${ }^{15}$

a) Tanah-tanah yang lebih dari batas maksimum

b) Tanah-tanah yang pemiliknya bertempat tinggal di luar daerah

c) Tanah-tanah swapraja dan bekas swapraja

d) Tanah-tanah lainnya.

${ }^{12}$ Indah Kusuma Pradini, Bedjo Sudjanto, and Nurjannah Nurjannah, 'Implementasi Program Sekolah Adiwiyata Dalam Peningkatan Mutu Pendidikan Di Sdn Tanah Tinggi 3 Kota Tangerang, Jurnal Green Growth Dan Manajemen Lingkungan, 7.2 (2019), 122-32<https://doi.org/10.21009/jgg.072.03>.

${ }^{13}$ Intan Merdeka Sari and Lego Karjoko, 'The Rationality on Regulation of Village Government Function on FirstTime Land Registration to Form the Land Ownership Certainty in Indonesia', International Journal of Multicultural and Multireligious Understanding, 5.4 (2018), 308 <https://doi.org/10.18415/ijmmu.v5i4.274>.

${ }^{14}$ I.G.A.K. Rachmi Handayani, Lego Karjoko, and Abdul Kadir Jaelani, 'Model Pelaksanaan Putusan Mahkamah Konstitusi Yang Eksekutabilitas Dalam Pengujian Peraturan Perundang-Undangan Di Indonesia', Bestuur, 7.1 (2019), 36-46<https://jurnal.uns.ac.id/bestuur/article/view/42700>.

15 Lego Karjoko, 'Setting of Plantation Land Area Limitation Based on Social Function Principles of Land Cultivation Rights To Realize Social Welfare-Promoting Plantation', Jurnal Dinamika Hukum, 17.1 (2017), 1 $<$ https://doi.org/10.20884/1.jdh.2017.17.1.606>. 
Secara hukum status tanah Keraton Kasepuhan Cirebon dari era Inggris, era Belanda, era Republik dan kemudian sampai era Reformasi adalah tanah wewenkon atau tanah hak turun temurun dari Kasultanan Kasepuhan Cirebon. Namun setelah berlakunya UUPA tahun 1960 seluruh tanah yang terkena objek landreform, hak tas tanahnya beralih kepada negara karena tanah wewengkon Keraton Kasepuhan Cirebon dianggap sebagai tanah swapraja atau bekas swapraja dan pihak yang dirugikan diberi ganti kerugian. ${ }^{16}$ Menurut Prof Boedi Harsono, swapraja adalah suatu wilayah pmerintah yang merupakan bagian dari daerah Hindia Belanda, yang kepala wilayahnya, (dengan sebutan Sultan, Sunan, atau nama adat yang lain) berdasarkan perjanjian dengan Pemerintah Hindia Belanda menyelenggarakan pemerintah sendiri (dalam Indische Zelfbestuur), di wilayah yang bersangkutan, masing-masing berdasarkan perjanjian tersebut serta adat-istiadat daerahnya masingmasing yang beraneka ragam. ${ }^{17}$

Bahwa yang dimaksud dengan daerah swapraja atau bekas swapraja adalah suatu daerah atau wilayah yang berdasarkan perjanjian dengan pemerintah Hindia Belanda diberikan hak untuk menyelenggarakan pemerintahan sendiri, tetapi merupakan bagian dari Hindia Belanda dan mengakui Raja Belanda sebagai penguasa tertinggi dengan wilayah yang telah ditentukan dalam perjanjian pemberian haknya. ${ }^{18}$ Di dalam penyelenggaraan haknya pemerintah daerah swapraja diberikan pula hak untuk memberikan tanah kepada pihak-pihak lain yang disesuaikan dengan peruntukannya sepanjang merupakan bangsa Indonesia asli, sedangkan terhadap pihak yang bukan bangsa Indonesia asli kewenangannya ada pada Gubernemen. Pemberian hak swapraja tersebut dilakukan antara Pemerintah Hindia Belanda dengan swapraja dan dituangkan dalam perjanjianperjanjian yang disebut Korte V arklaring. Oleh karena itu Keraton Kasepuhan Cirebon tidak dapat digolongkan daerah swapraja karena Penyerahan administrasi Pemerintah Sultan Cirebon tidak pernah dilakukan terhadap pihak colonial (Verrenigde Oost Indische Compagnie), melainkan kepada pihak Inggris yaitu dengan Akta 20 Juli 1813. Sedangkan menurut Pemerintah Kota Cirebon, tanah Keraton Kasepuhan Cirebon merupakan tanah swapraja atau bekas swapraja berdasarkan Diktum Ke-IV Undang-Undang Pokok Agraria : "Hak-hak dan wewenang atas bumi air dari swapraja atau bekas swapraja yang masih ada pada waktu mulai berlakunya undang-undang ini hapus dan beralih kepada negara". ${ }^{19}$

Status hukum tanah-tanah Keraton Kasepuhan Cirebon saat ini sebagian telah dimiliki oleh masyarakat serta sebagian lagi dikuasai negara, dengan beralaskan Pasal 1 Peraturan Pemerintah Nomor 224 tahun 1961. Tanah-tanah tersebut diberikan hak milik dengan dasar Surat Izin Menggarap (SIM) dan atas dasar Tanah Negara (TN) setelah menerima pelepasan hak dari Sultan Kasepuhan Cirebon. Tanah-tanah eks keraton kasepuhan tersebut memang sudah hampir seluruhnya dimiliki oleh masyarakat, tetapi tetap harus diperhatikan proses dan pembagian tanahtanah tersebut sudah benar sesuai prosedur atau memang ada indikasi perbuatan melawan hukum (1365 KUHper) yang diakukan oleh penguasa karena telah merampas hak Sultan Kasepuhan Cirebon. ${ }^{20}$ Apabila diasumsikan bahwa tanah wewengkon Kasultanan Kasepuhan Cirebon tersebut adalah Eks Swapraja, maka status hukum tanah-tanah Kasultanan Kasepuhan telah beralih kepada negara berdasarkan Diktum Keempat hururf A Undang-Undang Nomor 5 Tahun 1960 tentang Peraturan Dasar Pokok-Pokok Agraria (UUPA) dan atas tanah tersebut diredistribusikan sebagai

${ }^{16}$ I Gusti Ayu Ketut Rachmi Handayani, 'Pembentukan Peraturan Daerah Berbasis Lingkungan Dalam Rangka Mewujudkan Praktik-Praktik Good Governance Di Daerah', Yustisia Jurnal Hukum, 2.1 (2013), 66-73 <https://doi.org/10.20961/yustisia.v2i1.11072>.

${ }^{17}$ Febry Wulandari and W Waluyo, 'Efektivitas Pemanfaatan Dana Bagi Hasil Cukai Hasil Tembakau Dalam Bidang Kesehatan Di Kota Surakarta Tahun 2018', Jurnal Bestuur, 7.1 (2019).

18 Ahmad Dwi Nuryanto, 'Problem Penyidikan Tindak Pidana Pencucian Uang Yang Berasal Dari Predicate Crime Perbankan', Bestuur, 7.1 (2019), 54 <https://doi.org/10.20961/bestuur.v7i1.43437>.

${ }_{19}$ Delia Calinoiu and others, 'Parametric Modeling: A Simple and Versatile Route to Solar Irradiance', Energy Conversion and Management, 164 (2018), 175-87 <https://doi.org/10.1016/j.enconman.2018.02.077>.

${ }^{20}$ Nurlinda. 
objek dari ketentuan mengenai landreform dengan dasar hukum Pasal 1 Peraturan Pemerintah Nomor 224 Tahun 1961. Sangat berbanding terbalik jika diasumsikan bahwa tanah Keraton Kasepuhan tersebut adalah bukan dan tidak pernah menjadi swapraja, maka status hukum tanah Keraton Kasepuhan dikuasai sepenuhnya sebagai tanah adat/tanah wewengkon/hutan larangan milik Keraton Kasepuhan Cirebon. Permasalahannya, Keraton Kasepuhan berdasarkan bukti otentik tidak pernah menjadi swapraja tetapi tanah-tanah yang dikuasai secara turun-temurun atau tanah wewengkon Keraton Kasepuhan Cirebon tetap diredistribusikan oleh pemerintah. Jadi, status hukum tanah- tanah Keraton Kasepuhan saat ini tidak jelas status hukumnya. ${ }^{21}$

Hukum agrarian nasional yang telah berhasil diwujudkan oleh Undang-Undang Pokok Agraria menurut ketentuannya adalah didasarkan pada hukum adat, yang berarti bahwa hukum adat menduduki posisi yang sentral di dalam sistem hukum agrarian nasional. Hal yang demikian secara in abstracto mungkin dapat dengan mudah ditunjukkan dasar-dasarnya, akan tetapi bilamana kita akan melihat secara konkrit akan banyak timbul kesulitan dalam menentukan bagaimana tempat hukum adat yang dikatakan sebagai dasar daripada hukum agraria nasional itu. ${ }^{22}$ Dalam kenyataannya pengakuan terhadap hukum adat terkesan masih setengah-setengah yaitu masih adanya batasan-batasan tertentu. Hak ulayat telah disebutkan di dalam UUPA. Hal tersebut berarti pengakuan terhadap hak ulayat diperhatikan sepanjang hak tersebut menurut kenyataannya memang masih ada pada masyarakat hukum yang bersangkutan. Namun pengakuan hak ulayat tersebut belom diwujudkan ke dalam suatu peraturan pemerintah yang secara jelas dan terperinci, sehingga dalam pelaksanaannya muncul berbagai sengketa atau konflik mengenai hak ulayat tersebut karena belum ada pedoman yang khusus mengatur mengenai hak ulayat tersebut, seperti dalam pemasalahan ini mengenai tanah wengkon atau tanah hak turun temurun Kasultanan Kasepuhan Cirebon. ${ }^{23}$

Walaupun Undang-Undang Pokok Agraria telah ditegaskan bahwa hukum agraria nasional itu didasarkan pada hukum adat dan beberapa hak masyarakat hukum adat masih diakui namun pengakuan yang demikian tidaklah berpangkal pada penghargaan terhadap hukum adat dan kewenangan dari pada masyarakat hukum adat itu, melainkan berpangkal pada kewenangan pemerintah berdasarkan pada pola pemikiran dalam skala nasional. Dalam pelaksanaannya masih diperlukan adanya pngesahan mengenai apa sebenarnya yang menjadi kewenangan dari masyarakat hukum adat atas tanah dan mengarahkan kewenangan tersebut kepada hal-hal yang dapat menunjang kebijaksanaan pemerintah dalam mengelola soal pertanahan. ${ }^{24}$

\section{KESIMPULAN}

Bahwa pelaksanaan ketentuan Diktum ke IV huruf A UUPA dan Pasal 4 Peraturan Pemerintah Nomor 224 tahun 1961, mengenai tanah-tanah swapraja atau bekas swapraja di wilayah Eks Kesultanan Cirebon, khususnya terhadap tanah-tanah eks Kesultanan Kasepuhan Cirebon, menyebabkan timbulnya "konflik pertanahan" yang berkepanjangan, kerena tidak adanya kejelasan mengenai status tanah tersebut. Hingga saat ini belum juga bisa diambil suatu kesimpulan yang tegas, apakah Cirebon merupakan daerah swapraja/bekas swapraja atau bukan. Menurut Pemerintah Kota Cirebon, tanah Keraton Kasepuhan Cirebon merupakan tanah swapraja atau

${ }^{21}$ Lusia Savitri Diah Candrasari and Lego Karjoko, 'The Principle of Social Function of Land Cultivation Right in Agritourism Accommodation in Indonesia', International Journal of Multicultural and Multireligious Understanding, 5.2 (2018), $271<$ https://doi.org/10.18415/ijmmu.v5i2.374>.

22 A Respati and others, 'The Reconstruction of Ecotourism Model Based on Resources and Local Wisdom', International Journal of ..., 13.4 (2017), 138-43 <http://ijbel.com/wp-content/uploads/2017/10/LAW-214.pdf>.

23 Liana E Susanti, 'Economic Law Creation Beautiful Global Indonesia', Bestuur, 7.1 (2019), 47-53 $<$ https://jurnal.uns.ac.id/bestuur/article/view/42701>.

24 C.D. Balenina, 'Partisipasi Masyarakat Dalam Pengelolaan Desa Sampah Mandiri Di Desa Kalisoro, Tawangmangu, Kabupaten $\quad$ Karanganyar', $\quad B e s t u u r, \quad 7.1 \quad$ (2019), 26-35 <https://doi.org/https://dx.doi.org/10.20961/bestuur.v7i1.28418>. 
bekas swapraja berdasarkan Diktum Ke-IV Undang-Undang Pokok Agraria : "Hak-hak dan wewenang atas bumi air dari swapraja atau bekas swapraja yang masih ada pada waktu mulai berlakunya undang-undang ini hapus dan beralih kepada negara". Apabila diasumsikan bahwa tanah wewengkon Kasultanan Kasepuhan Cirebon tersebut adalah Eks Swapraja, maka status hukum tanah-tanah Kasultanan Kasepuhan telah beralih kepada negara berdasarkan Diktum Keempat hururf A Undang-Undang Nomor 5 Tahun 1960 tentang Peraturan Dasar Pokok-Pokok Agraria (UUPA) dan atas tanah tersebut diredistribusikan sebagai objek dari ketentuan mengenai landreform dengan dasar hukum Pasal 1 Peraturan Pemerintah Nomor 224 Tahun 1961. Sangat berbanding terbalik jika diasumsikan bahwa tanah Keraton Kasepuhan tersebut adalah bukan dan tidak pernah menjadi swapraja, maka status hukum tanah Keraton Kasepuhan dikuasai sepenuhnya sebagai tanah adat/tanah wewengkon/hutan larangan milik Keraton Kasepuhan Cirebon. Permasalahannya, Keraton Kasepuhan berdasarkan bukti otentik tidak pernah menjadi swapraja tetapi tanah-tanah yang dikuasai secara turun-temurun atau tanah wewengkon Keraton Kasepuhan Cirebon tetap diredistribusikan oleh pemerintah. Jadi, status hukum tanah- tanah Keraton Kasepuhan saat ini tidak jelas status hukumnya.

\section{REFERENCES}

Ayu, Isdiyana Kusuma, 'Problematika Pelaksanaan Pendaftaran Tanah Melalui Pendaftaran Tanah Sistematis Lengkap Di Kota Batu', Legality: Jurnal Ilmiah Hukum, 27.1 (2019), 27 <https://doi.org/10.22219/jihl.v27i1.8956>

Balenina, C.D., 'Partisipasi Masyarakat Dalam Pengelolaan Desa Sampah Mandiri Di Desa Kalisoro, Tawangmangu, Kabupaten Karanganyar', Bestuur, 7.1 (2019), 26-35 <https://doi.org/https://dx.doi.org/10.20961/bestuur.v7i1.28418>

Calinoiu, Delia, Nicoleta Stefu, Remus Boata, Robert Blaga, Nicolina Pop, Eugenia Paulescu, and others, 'Parametric Modeling: A Simple and Versatile Route to Solar Irradiance', Energy $\begin{array}{llll}\text { Conversion and } & \text { Management, } & 164 & \text { (2018), }\end{array}$ <https://doi.org/10.1016/j.enconman.2018.02.077>

Candrasari, Lusia Savitri Diah, and Lego Karjoko, 'The Principle of Social Function of Land Cultivation Right in Agritourism Accommodation in Indonesia', International Journal of $\begin{array}{lllll}\text { Multicultural and Multireligious Understanding, } 5.2 & \text { (2018), } 271\end{array}$ <https://doi.org/10.18415/ijmmu.v5i2.374>

Earnestly, Femi, 'Analisis Kadar Klorida, Amoniak Di Sumber Air Tanah Universitas Muhammadiyah Sumbar Padang', Jurnal Katalisator, 3.2 (2018), 89 <https://doi.org/10.22216/jk.v3i2.3392>

ham Abbas, Marten Bunga, Salmawat, Hardianto Djanggih, 'The Wife's Rights Over Mahar Sompa Of Traditional Marriage In Bugis Makassar (The Analysis of PA Decission Nomor 25/Pdt.P/2011/PABlk)', Kanun Jurnal Ilmu Hukum, 20.2 (2018), 203-18

Handayani, I.G.A.K. Rachmi, Lego Karjoko, and Abdul Kadir Jaelani, 'Model Pelaksanaan Putusan Mahkamah Konstitusi Yang Eksekutabilitas Dalam Pengujian Peraturan PerundangUndangan Di Indonesia', Bestuur, $7.1 \quad$ (2019), 36-46 $<$ https://jurnal.uns.ac.id/bestuur/article/view/42700>

Kajoko, L, Zaidah Nur Rosidah, and I.G.A.K. Rachmi Handayani, 'Refleksi Paradigma Ilmu Pengetahuan Bagi Pembangunan Hukum Pengadaan Tanah', Bestuur, 7.1 (2019), 1-14 $<$ https://jurnal.uns.ac.id/bestuur/article/view/42694>

Karjoko, Lego, 'Setting of Plantation Land Area Limitation Based on Social Function Principles of Land Cultivation Rights To Realize Social Welfare-Promoting Plantation', Jurnal Dinamika Hukum, 17.1 (2017), 1 <https://doi.org/10.20884/1.jdh.2017.17.1.606> 
Ketut Rachmi Handayani, I Gusti Ayu, 'Pembentukan Peraturan Daerah Berbasis Lingkungan Dalam Rangka Mewujudkan Praktik-Praktik Good Governance Di Daerah', Yustisia Jurnal Hukum, 2.1 (2013), 66-73 <https://doi.org/10.20961/yustisia.v2i1.11072>

Luthfi, Ahmad Nashih, 'Reforma Kelembagaan Dalam Kebijakan Reforma Agraria Era Joko Widodo-Jusuf Kalla [nstitutional Reform in the Joko Widodo-Jusuf Kalla Era of Agrarian Reform Policy]', Jurnal Bhumi, 4.2 (2018), 153 <https://doi.org/10.31292/jb.v4i2.276.g252>

Marryanti, Septina, and Yudha Purbawa, 'Optimization of Factors That Affect The Success of Complete Systematic Land Registration’, BHUMI: Jurnal Agraria Dan Pertanahan, 4.2 (2018), 190-207

Mujiburohman, Dian Aries, 'Potensi Permasalahan Pendaftaran Tanah Sistematik Lengkap (Ptsl)', BHUMI: Jurnal Agraria Dan Pertanahan, 4.1 (2018) < https://doi.org/10.31292/jb.v4i1.217>

Murni, Christina Sri, 'Peralihan Hak Atas Tanah Tanpa Sertifikat', Lex Librum: Jurnal Imu Hukum, 4.2 (2018), 691 <lexlibrum.id/index.php/lexlibrum/article/download/108/pdf>

Nurlinda, Ida, 'Perolehan Tanah Obyek Reforma Agraria (Tora) Yang Berasal Dari Kawasan Hutan: Permasalahan Dan Pengaturannya', Veritas et Justitia, 4.2 (2018), 252-73 $<$ https://doi.org/10.25123/vej.2919>

Nuryanto, Ahmad Dwi, 'Problem Penyidikan Tindak Pidana Pencucian Uang Yang Berasal Dari $\begin{array}{lllll}\text { Predicate Crime } \quad \text { Perbankan', Bestuur, } & 7.1 & \text { (2019), } & 54\end{array}$ <https://doi.org/10.20961/bestuur.v7i1.43437>

Permatasari, Elfira, Habib Adjie, and Hardianto Djanggih, 'Perlindungan Hukum Kepemilikan Tanah Absentee Yang Diperoleh Akibat Pewarisan', Varia Justicia, 14.1 (2018), 1-9 $<$ https://doi.org/10.31603/variajusticia.v14i1.2052>

Pradini, Indah Kusuma, Bedjo Sudjanto, and Nurjannah Nurjannah, 'Implementasi Program Sekolah Adiwiyata Dalam Peningkatan Mutu Pendidikan Di Sdn Tanah Tinggi 3 Kota Tangerang,, Jurnal Green Growth Dan Manajemen Lingkungan, 7.2 (2019), 122-32 <https://doi.org/10.21009/jgg.072.03>

Respati, A, E Purwanto, S Santoso, and ..., 'The Reconstruction of Ecotourism Model Based on Resources and Local Wisdom', International Journal of .., 13.4 (2017), 138-43 <http://ijbel.com/wp-content/uploads/2017/10/LAW-214.pdf>

Sari, Intan Merdeka, and Lego Karjoko, 'The Rationality on Regulation of Village Government Function on First-Time Land Registration to Form the Land Ownership Certainty in Indonesia', International Journal of Multicultural and Multireligious Understanding, 5.4 (2018), 308 <https://doi.org/10.18415/ijmmu.v5i4.274>

Subekti, Rahayu, Lego Karjoko, and Wida Astuti, 'Kebijakan Tata Ruang Di Kabupaten Kutai Kartanegara (Studi Valorisasi Ruang)', Yustisia Jurnal Hukum, 2.2 (2013) $<$ https://doi.org/10.20961/yustisia.v2i2.10184>

Susanti, Liana E, 'Economic Law Creation Beautiful Global Indonesia', Bestuur, 7.1 (2019), 47-53 $<$ https://jurnal.uns.ac.id/bestuur/article/view/42701>

Wulandari, Febry, and W Waluyo, 'Efektivitas Pemanfaatan Dana Bagi Hasil Cukai Hasil Tembakau Dalam Bidang Kesehatan Di Kota Surakarta Tahun 2018', Jurnal Bestuur, 7.1 (2019) 